\title{
Government Responses to Foreign Worker Demand During Economic Crises
}

The Cases of Britain and France 2008-2013

\author{
Camilla Devitt
}

CMS 2 (4): 445-467

DOI: 10.5117/CMS2014.4.DEVI

\begin{abstract}
With the aim of developing existing theories of labour immigration policy, I focus on the question of persisting demand for foreign workers during economic downturns and how governments attempt to respond to this. The argument is that, apart from turning a blind eye to irregular labour migration, there are two ways in which governments respond to demand for migrant labour during economic hard times. First, despite a rhetorical emphasis on restricting labour immigration, they continue to facilitate the entry of highly skilled labour migrants and the employment of migrants who enter a country with a non-economic motive. Second, they encourage resident workers to take up jobs in occupations where migrant workers are concentrated. This hypothesis is borne out in my exploration of French and British government responses to foreign labour demand between 2008 and 2013.
\end{abstract}

Keywords: labour immigration, labour supply, policy, Britain, France, economic downturn

\section{Introduction}

The focus of the existing literature on immigration policy differs depending on whether the context is good or bad economic times. In the good times, scholars analyse government facilitation of labour immigration and the role of stakeholders, such as employers and trade unions, in the policy process (Krings, 2009; Menz, 2005). In the bad times, the emphasis is overwhelmingly on government attempts to control and restrict immigration, 
particularly labour immigration (Cornelius et al., 1994; Guiraudon and Joppke 2001). The dominant image presented in the latter analyses is of a gap or disjuncture between public opinion and immigration policies and above all between policy and levels of immigration (Freeman 1995; Hollifield 2004; Joppke, 1998). The argument is that the preference among the public at large, and at times also of governments, for low levels of immigration is often not reflected in immigration policy or in actual levels of immigration due to economic and political liberal constraints on government action. For example, Freeman has posited that organised interests, for example employer organisations, are better able to influence policy than the public and generally push for liberal labour immigration policies (1995). Similarly, the gap between labour immigration policy and levels of immigration can be explained by the fact that employers, arguably especially during economic downturns, have a large appetite for relatively cheap and compliant migrant labour. Consequently, even if labour immigration policies are restrictive, the strong demand for and supply of foreign labour results in irregular labour immigration. Furthermore, some scholars emphasise that governments are cognisant of the economic benefits of irregular migration and consequently tolerate it (Castles, 2004).

This article focuses more closely on the question of persisting demand for foreign workers during economic downturns and how governments attempt to respond to this. The argument is that, apart from turning a blind eye to irregular labour migration, there are two ways in which governments respond to migrant labour demand during economic slumps. First, they continue to facilitate the entry and employment of certain categories of migrants who are considered to be important labour market actors and whose entry they deem will be the least likely to upset public opinion - and consequently their chances of re-election. I refer in particular to facilitating the entry of highly skilled labour immigrants, with skills ostensibly not available on the domestic market and whose education is perceived to facilitate their integration into society (Ruhs and Martin, 2008). But I also refer to the continuing provision of labour market access to "indirect labour migrants," those who enter a country with a non-economic motive, for example family reunification or study. As the government does not permit the latter to enter in order to work, it is, I argue, less likely to be blamed for irresponsibly facilitating labour immigration in the context of an economic slump. Second, they try to substitute migrant workers ${ }^{1}$ with resident unemployed workers, by encouraging and obliging the latter to engage in training and take up employment in occupations in which migrant workers are significantly employed. It should be noted that 
the opposing pressures of employer demand for foreign workers and public opposition to immigration are relatively constant fixtures in the minds of immigration policy makers. However, the subjective pressure felt by policymakers to restrict labour immigration is much stronger during periods of economic downturn and rising unemployment, as can be seen by changes in government policy on immigration across advanced democracies during these periods (OECD, 2009).

Important theorising on immigration policy in Europe in the context of inclement economic conditions was done between the 1970s and 1990s. However, the politico-economic climate has changed considerably since the late 1990s. Governments now work firmly within a paradigm of global economic integration. Human capital competitiveness has become a key policy aim in most European states and the facilitation of highly skilled migrant workers has been viewed, since the late 1990s, as a requirement of open competitive economies (Devitt, 2010). In this sense, a complete closure to labour immigration, as occurred in the early 1970 in much of North West Europe, is, I contend, highly unlikely today. Analyses of government reactions to the current economic crisis, in terms of immigration, have so far been largely produced by international organisations such as the OECD and IOM. The focus of these analyses has been on changes to immigration policy rather than on the question of labour supply during economic crises. This paper thus aims to fill gaps in the literature in two main ways; it approaches immigration policy in economic hard times in a novel way by focusing on the question of government responses to on-going labour demand; and it focuses on the current international economic crisis, which has occurred in a markedly different politico-economic context than that of the 1970 .

In particular, I explore how governments in two large European states, Britain and France, have attempted to respond to foreign labour demand between 2008 and 2013, based on analysis of official documents and interviews with policymakers and stakeholders in each state (see appendix). The paper begins with a brief description of labour immigration policy in the two countries in the period prior to the international financial crisis, between the late 1990s and 2007, in order to assist readers in gauging the level of policy change in the following period. Then, the paper compares government policy across three dimensions: highly skilled labour immigration; indirect labour immigration; and substituting migrant workers with resident workers. I then provide an explanation for differences in policy choice in the two states and finish with some concluding remarks on how this analysis contributes to immigration policy theory. 


\section{Labour immigration policies late 1990s-2007}

In the late 1990s, the discourse on labour immigration began to change in Western Europe in the context of concerns regarding demographic decline and labour shortages. British Labour governments decisively broke with previous discourse, emphasising the contribution that economic migration can make to the economy. The new policy approach which developed was based around the concept of "managed migration" (Home Office, 2002). Managed migration involves strong controls on unauthorised and noneconomic migration, in particular asylum-seeking, and the facilitation of economic migration.

Between 2000 and 2004, the work permit system was eased and new schemes were introduced for high and low skilled workers. The number of work permits and first permissions issued between 1995 and 2005 more than tripled (Somerville, 2007). New Labour also decided not to impose restrictions on the free movement of workers from the new EU member states on their accession on the $1^{\text {st }}$ of May 2004. The strategy was to fill low skilled labour needs with workers from the new member states and restrict non-EU migration to the highly skilled. The numbers were far greater than expected and public opinion polls generally showed an increasingly negative stance on immigration, with a majority preferring a reduction in inflows (Boswell, 2009).

In response to growing public concerns about immigration, Labour's third term saw a major consultation on how to manage economic migration, the outcome of which was the Points Based System (PBS), which was rolled out from 2008. It consolidated existing work and study routes into five main categories or "tiers". Prospective immigrants gain entry if they reach the required threshold of points, which are based on various criteria, depending on the particular route through which they are applying. For example, in the new Tier 2 general, prospective immigrants gain points for a "graduate" job offer with a licensed "sponsor" (employer), prospective earnings, English language ability and maintenance funds. Furthermore, an independent advisory body on immigration policy was created in June 2007: the Migration Advisory Committee (MAC).

Since the late 1990s, the French debate on labour immigration has been fed by concerns over the integration of resident migrant workers and descendants of immigrants, as well as the objective of ensuring economic competitiveness in a globalised world. The cross-party aim of gearing labour immigration towards the highly skilled - and, particularly among the centre right, reducing levels of family reunification - has become progres- 
sively stabilised. The basic consensus on labour immigration has been hidden behind highly charged political conflict on other aspects of the immigration regime, for example, rights to family reunification and the treatment of irregular migrants. Immigration had become a major political issue in the early 1980 s with the growth of the Front National (FN) antiimmigration party (Bertossi 2008).

The first elements of a selective immigration policy were introduced in 1998 by the centre-left government of Prime Minister Lionel Jospin, including a special immigration status for scientists and scholars (Weil, 2006). Stimulated by concerns about economic competitiveness, the policy of facilitating economic immigration was further developed by Minister of the Interior, Nicolas Sarkozy, in the following centre-right government. Sarkozy maintained that at that time legal immigration consisted only of immigration subie, family and asylum inflows, which France was forced to accept, as opposed to immigration choisie, which was one selected to respond to the economy's needs and integration capacity (Lochak, 2006). The $24^{\text {th }}$ July 2006 Immigration and Integration Law (loi relative à l'immigration et à l'intégration) aimed to facilitate the access to the labour market of skilled foreign workers and students. For example, the law introduced shortage occupation lists and a "Skills and Talents" permit for highly skilled people. On election to the French presidency in May 2007, Sarkozy ordered the Minister for the Interior to aim to make economic immigration $50 \%$ of total migrant inflows.

Between 2006 and 2008, economic migration to France rose from a total of 11,678 to 21,352 . This growth was, however, unlikely to have been the result of the 2006 law. The decree establishing the shortage occupation list for nonEU workers was only published in 2007 and all of the new permits and categories represent small numbers. Four years after its introduction, only 317 foreign nationals were issued with Skills and Talents permits in 2010.

\section{$3 \quad$ British and French labour supply policies 2008-2013}

The international financial crisis of 2008 led to the re-introduction of restrictions on labour immigration in most European states. As noted above, attempts to place stronger controls on labour immigration pre-dated this crisis in Britain and can be seen as a reaction to the size of migratory inflows following the Eastern enlargement of 2004. However, attempts to reduce levels of labour immigration came following the crisis in both states. At the same time, in order to ensure that employers could continue 
to access skills, highly skilled labour immigration was protected. Furthermore, both states continued to allow the labour market participation of family migrants, though student labour market participation was constrained in Britain. Finally, the policy of attempting to substitute immigrant labour with resident labour was more developed in the British case.

\subsection{Highly skilled labour immigration}

British immigration policy shifted sharply from expansive to restrictive between 2009 and 2010. However, while governments have attempted to reduce numbers of non-EU labour immigrants by, for example, raising the skill threshold and imposing a numerical cap on certain inflows, significant numbers of highly skilled immigrants were excluded from the new restrictions. Indeed, we can see a disjuncture between rhetoric and policy reminiscent of that identified in scholarship on government responses to irregular labour immigration (Guiraudon and Joppke, 2001). Despite strong political commitments to reducing immigration, there is clearly a simultaneous economic interest, in this case voiced by multi-national companies and other actors, in keeping the door ajar.

In France, the volte-face on labour immigration occurred later than in Britain, two years later in fact. This was partly because the French economy began to feel the heat of the crisis later than in Britain (in 2009). However, levels of labour immigration, already low compared to Britain, did not fall sharply in France. Thus it appears that despite the crisis, government officials saw fit to continue to permit skilled migrants to enter the country.

\subsubsection{Britain}

With the onset of the economic crisis in 2008, the approach to labour immigration in Britain changed definitively. In that year, the House of Lords Select Committee on Economic Affairs published a report on the "Economic Impact of Immigration", which questioned the positive consensus regarding the benefits of immigration. It maintained that there was a risk that too much migration would reduce incentives for training, and was contributing to the increase in housing prices, among other problems (Devitt, 2010). The Labour government began to make qualitative adjustments to the PBS in order to reduce inflows, for example strengthening the Resident Labour Market Test (RLMT) ${ }^{2}$ in 2009 by lengthening the required advertising period to four weeks.

Mirroring Thatcher's Conservative party victory in the 1979 elections (Schain, 2006), the Conservative party gained votes in the 2010 general 
election due to its tough line on immigration. As Prime Minister David Cameron stated in March 2013:

As I've long argued, under the previous government immigration was far too high and the system was badly out of control. Net migration needs to come down radically from hundreds of thousands a year, to just tens of thousands, and as we bring net migration down so we must also make sure that Britain continues to benefit from it (Cameron, 2013).

Since in government, the Conservative-Liberal Democrat coalition have made some qualitative changes to the largest Tier of the PBS, Tier 2 (for highly skilled migrant workers with a job offer in the UK), in order to reduce the number of applicants; raising the job skill, language and the minimum pay thresholds. Furthermore, the list of occupations on the shortage occupation list was also shortened in September 2011.

Most controversially, in line with the Conservative electoral commitment to reduce net migration to the "tens of thousands, not hundreds of thousands", the government introduced an annual cap on some categories of non-EEA ${ }^{3}$ economic migrants. Since April 2011, the annual cap for Tier 2 has been set at 20,700. The government also decided to limit Tier 1 , the entry-channel which does not require a job offer in the UK prior to entry, to investors, entrepreneurs, and people of "exceptional talent" (for whom there are a maximum of 1,000 permits).

There has, however, been a general acceptance of the Conservative restrictions on immigration among the main parties and stakeholders, who display little appetite to oppose the general thrust of policy. While the Labour and Liberal Democrat parties did not support the idea of a cap on labour inflows, qualitative restrictions appear to be less controversial. Only a few employer associations, which are affected by the restrictions, in particular the ethnic catering industry, have been vociferously critical of current policy (Interview BIS1, BHA). The trade unions have also tempered their pro-migrant perspective and have begun to put more emphasis on the need to upskill local workers (Interviews HO, TUC).

This, I argue, can be partly explained by the fact that the changes introduced by the Conservatives are far less dramatic than might appear from the party rhetoric. Indeed, Intra-Company Transfers (ICTs) - workers moving within multi-national companies (MNCs) - are not subject to the cap, despite the MAC recommendation to the contrary, due to the MNC employer lobby and diplomatic pressure from the Indian and Japanese governments (Interview MAC). This is significant as the ICT route is the most 
used route of the PBS system (about $70 \%$ of Tier 2 applications) and it is the only one, which does not necessitate an assessment of whether there are suitable candidates in the resident labour force (MAC 2009). The Tier 2 limit also does not apply to other categories including those who apply from within the UK (in-country applicants) or to those who will earn over $£ 150,000$ per annum. Furthermore, the cap on Tier 1 and Tier 2 routes introduced in April 2011 was substantially undersubscribed. This is partly accounted for by the fact that the cap was set at a relatively high level; indeed, the number of permits available under Tier 2 for 2011-12 was greater than the number of certificates issued under Tier 2 (excluding ICTs) in 2009 (Migration Observatory, 2011).

Moreover, while the Labour government made the RLMT more onerous in 2009, there is no public certification of the process or pre-admission checks and post-admission checks on employers are infrequent. In 2009, the MAC asserted that there may be a case for introducing certification; however, governments have not done so due to the cost it would entail and a political antipathy towards red tape and regulation (Interview MAC).

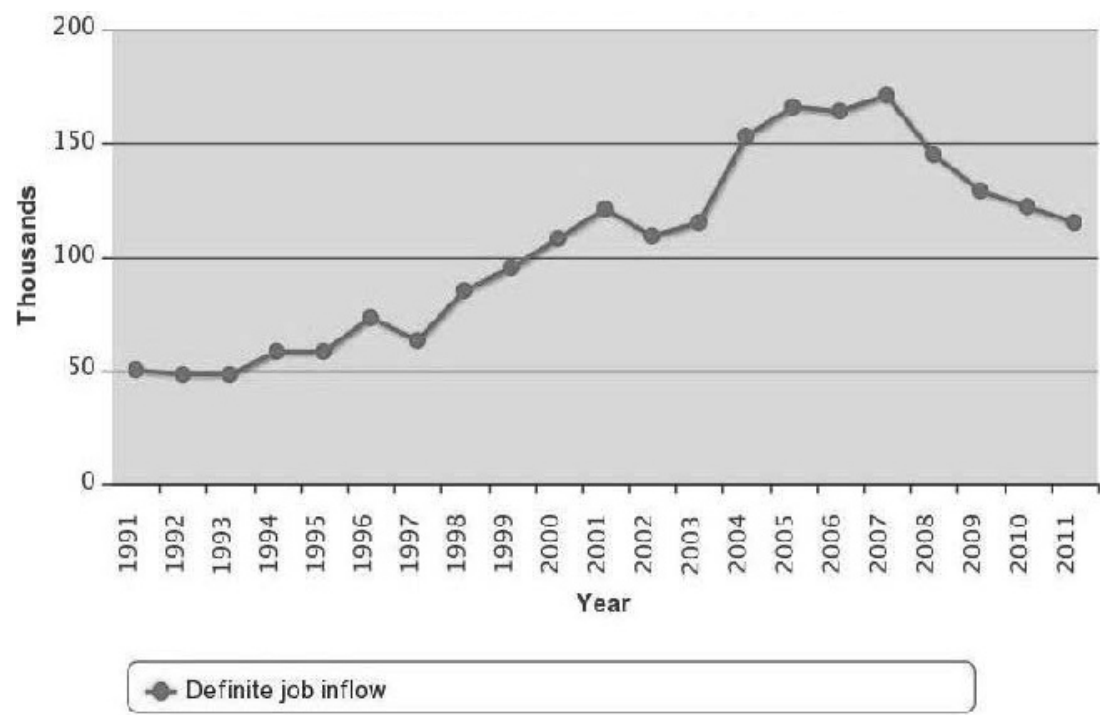

Figure 1 Work-related migration to the UK 1991-2011

Source: Migration Observatory Oxford 2014 
Indeed, the number of people entering the UK with a definite job fell from 145,000 in 2008 to 115,000 in 2011 (see Figure 1), demonstrating a persisting demand for migrant workers in Britain despite the crisis. ${ }^{4}$

\subsubsection{France}

The international financial crisis did not have an immediate effect on immigration policy in France. Indeed, France was the first EU member state to transpose the European Directive 2009/50/EC of the $25^{\text {th }}$ of May 2009 on conditions of entry and residence of third-country nationals for the purposes of highly qualified employment with the law of the $16^{\text {th }}$ of June 2011. Furthermore, the French Office for Immigration and Integration (OFII) "Labour Immigration" website was created in April 2010 in order to make the French labour immigration procedures more accessible to employers and prospective migrants.

However, the approach of the government to labour immigration changed markedly from 2011. Referring to the economic crisis and rise in unemployment from $7 \cdot 7 \%$ at the end of 2007 to nearly $10 \%$, in late May 2011, Claude Géant, Minister for the Interior, declared that total immigration inflows were to be reduced by 20,000 and labour immigration by $50 \%$. He maintained that "contrary to myth, France does not need skilled foreign workers. Last year, 730 foreign masons entered the territory; yet when Pôle Emploi (public employment agency) advertises 20 mason jobs, 100 jobseekers in France apply" (Le nouvel observateur 2013). A decree of the $31^{\text {st }}$ of May 2011 from the Ministers of Interior and Labour aimed to reduce the numbers of permits issued (d. l. o.-m. Ministère de l'Intérieur, des collectivités territoriales et de l'immigration et Ministère du travail, de l'emploi et de la santé, 2011). The prefects were instructed to be particularly restrictive regarding those with job offers, which were not particularly skilled, as well as students applying for a temporary residence card in order to search for a job or changing status from student to labour migrant. Furthermore, the shortage occupation list for non-EEA nationals was also reduced from 30 occupations, defined on a regional basis, to 14 occupations for the entire country, by means of a decree from the Interior Ministry $\left(11^{\text {th }}\right.$ of August 2011).

However, the numbers of first work permits issued to non-EU nationals did not fall sharply between 2010 and 2012. They decreased just slightly from 18,759 in 2010 to an estimated 17,354 in 2012 (see Table 1) (Ministère de l'Intérieur 2013). 
Table 1 First work-related residence permits issued to non-EU nationals 2006-2012 (in thousands)

\begin{tabular}{|c|c|c|c|c|c|c|}
\hline 2006 & 2007 & 2008 & 2009 & 2010 & 2011 & 2012 \\
\hline 12,126 & 12,154 & 21,792 & 20,607 & 18,759 & 18,303 & $\begin{array}{l}17,354 \\
\text { (estimate) }\end{array}$ \\
\hline
\end{tabular}

Source: Ministère de l'Intérieur 2013 p. 23

This suggests that the hardening of the RLMT criteria did not have a huge effect on inflows. It may be explained by the fact that there were political rather than economic motives behind the new restrictions imposed on labour immigration and officials were consequently perhaps not under pressure to implement the more restrictive policy in practice. Indeed, the rhetoric was undoubtedly an attempt to siphon some of Marine Le Pen's electorate; opinion polls showed Marine Le Pen (FN) as a serious contender for the 2012 Presidential elections, with a few polls even suggesting that she could win the first round of the election (The Economist, 2012).

This return of a restrictive approach to labour immigration - at least on a rhetorical and policy level - has been tempered during the Presidency of Francois Hollande. On the 6th of May 2012, the Socialist candidate Hollande won the presidential elections runoff with a vote of $51.63 \%$ to Sarkozy's $48.37 \%$. A parliamentary debate on immigration took place in April 2013 based on a Ministry of the Interior report on economic and student immigration (Ministère de l'Intérieur, 2013). This report notes the low level of highly skilled migration to France, queries whether the RLMT might be made less onerous and discusses the benefits of student immigration; suggesting that the Socialist government has an expansive approach to economic immigration. An immigration bill to be published in 2014 will introduce pluri-annual permits and is also expected to ease the RLMT (Interview OLI2).

\subsection{Indirect labour immigration}

Indirect labour immigration, in particular family and student migrants' access to the labour market has been more protected in France than in Britain during the current economic downturn. While the British coalition government examined the question of whether family migrants should be permitted to access the British labour market in the context of the economic downturn, French governments have not - at least transparently questioned family migrants' participation in the labour market. Furthermore, the Sarkozy government's attempt to restrict student access to the labour market was unsuccessful, unlike that of the British government. 


\subsubsection{France}

Family migration is the object of contradictory policy signals in France. On the one hand, centre-right governments have been intent on reducing levels of family migration, on the basis that it is not beneficial to the French economy or society, and on the other, it is recognised by most stakeholders that family migrants represent an important source of labour for French firms. Indeed, regarding the latter, non-labour migrant entries into the labour market more than doubled since 1998, representing over fifty per cent of new active foreigners in 2003 (Bertossi, 2008).

There have been numerous attempts to stem family migration over the past decade, for example a 2007 law introduced a minimum level of French language to be tested when the candidate applies for a visa to France, as well as the demonstration that s/he endorses the main French constitutional principles. Sarkozy recognised that family migrants were often employed in the French labour market, however, he argued that the problem was that they were mainly low-skilled and were thus adding to the lowskilled labour force.

Notably, however, while repeated attempts have been made by centreright governments to reduce levels of family immigration, the idea of restricting family migrants' access to the labour market has not been examined by government, as it has been in the UK. Indeed, the importance of non-economic migrants in terms of labour market activity in France was noted by the Centre for Strategic Analysis in the Prime Minister's office in 2006, when it maintained that "we cannot restrict the concept of economic immigration to 'direct entries"' (CAS, 2006 p. 65).

French legislation and decrees have facilitated non-EU students' access to the labour market since the 1990s. Student immigration has represented the second largest inflow to France after family immigration since 2006: nearly a third of inflows in 2010. Between 2009 and 2010, the growth rate was particularly high $(+12 \%)$.

Bertossi maintains that the policy of training foreign elites in order to exert influence on their countries of origin, dominant in the 1990s, has shifted to a new policy, which aims to retain foreign students in order to ensure the competitiveness of the French economy (2008). The law of 2006 established that students can work during their studies with an annual limit of 964 hours (60\% of a full-time job, compared to $50 \%$ previously). Also, students graduating from a French university with a Masters degree can reside in France for six months in order to search for a job. The number of authorisations to work issued to students increased significantly since 
the late 1990s, in tandem with the general rise in numbers of foreign students (from 11,000 to 40,000 between 1998 and 2003).

As discussed above, a decree of the 31st of May 2011 from the Ministers of Interior and Labour instructed prefects to be particularly restrictive towards students applying for jobs on graduation. However, due to protests from students and universities (the "Collectif du 31 mai" movement), a new decree of the 12th of January eased these restrictions, making reference to the need to ensure the attractiveness of the higher education system and competitiveness of French firms (d. l. o.-m. Ministère de l'Intérieur, des collectivités territoriales et de l'immigration, Ministère du travail, de l'emploi et de la santé et Ministère de l'Enseignment Supérieur et de la Recherche 2012). On entering government, the Socialist government annulled the decree. The strength of the opposition to this decree is due to the fact that the majority of people issued with work permits in France are already resident in France with student visas. Indeed, the Hollande government is keen to increase the levels of student migration to France as it is seen as a source of skilled workers (Interview Medef).

\subsubsection{Britain}

In Britain, labour immigrants' dependants can participate in the labour market provided that the PBS immigrant has been granted more than 12 months' permission to stay in the UK. Allowing the employment of PBS migrants' spouses/partners provides employers with additional labour and reduces demand for an opening of Tier 3 of the PBS for temporary lowskilled workers (which has remained closed since the establishment of the PBS). In the second quarter of 2008, 27.3 per cent of the total immigrant stock had entered the UK in the previous five years to join a family or spouse; a larger percentage than those entering for work or study or any other reason. Over half of spouses/ partners were employed (59\%) and 81 per cent of spouses/partners were employed in unskilled occupations (MAC, 2009).

In the context of rising concern regarding unemployment and displacement of resident workers with migrant workers, the MAC was asked to assess the economic contribution made by the dependants of PBS migrants and their role in the labour market in February 2009. In its report in August of that year, the MAC maintained that there was no reason to conclude that greater restrictions on working rights for dependants would lead to improved outcomes, either for UK workers or for the UK economy (MAC, 2009).

Student migration has constituted the largest category of migration to 
the UK during the current economic downturn. However, a smaller proportion of students participate in the labour market than family migrants. According to LFS data ${ }^{5}$, only about 1 in 4 foreign-born students (both EU and non-EU nationals) have paid employment (UKBA, 2010).

Concerns over foreign students using the student migration system as an entry-way into the labour market prompted the Labour government to restrict the work rights of students on courses below degree level and raise the minimum level of English language study permitted under Tier 4 (the PBS channel for students). However, the 2009 LFS suggests that there is significant working in breach. For those studying below degree level, 53 per cent reported working more than 21 hours per week (UKBA 2010).

In March 2011, following a public consultation on the student immigration system, the Government announced that the Tier 1 Post-study Work visa category would close from April 2012. The Post-study Work visa enabled foreign students to remain in the UK for up to two years after obtaining a UK degree. Since April 2012 international graduates are only able to remain in the UK by switching into Tier 2 of the points-based system or if they have a strong business proposition (under new provisions for student entrepreneurs).

\subsection{Substituting labour immigrants with resident workers}

The two labour immigration systems aim to ensure that foreign workers are only allowed to enter to take up a job when no suitable resident workers are available for the job. However, over the past five years, British governments have arguably placed more emphasis - at least at the discursive level - on finding alternatives for migrant workers than French governments have. The British MAC has an articulated system for investigating whether employers in different sectors are attempting to find alternatives to bringing in foreign workers and governments have introduced training programmes and schemes which aim to enable/induce resident workers to take up jobs in sectors which employ significant numbers of migrant workers.

\subsubsection{Britain}

Faced with growing complaints about the impact of Eastern European migration on domestic workers, in June 2007, Prime Minister Gordon Brown (Labour) famously called for "British workers for British jobs" in a speech to the GMB Union (Summers, 2009). While the Conservative leader David Cameron accused Brown of pandering to protectionist fears in 20079, the Conservatives in government have emphasised the need to ensure 
that resident workers can compete with migrants, with a particular focus on the British low-skilled. In July 2011, referring to new data that more than half of new jobs in the past year had been taken by foreigners, the Work and Pensions Secretary, Iain Duncan Smith, asserted that the welfare-towork schemes would fail if immigration were not more strictly controlled. Duncan Smith urged employers to give British workers a "fair chance" and not to automatically revert to foreign workers (Sparrow, 2011).

The main substitute for labour immigration discussed in the UK is the training and "upskilling" of the resident labour force in order to provide employers with the skills they need and reduce demand for foreign skills. Other alternatives, in particular raising wages and improving working conditions, are less emphasised in the public debate. The focus on skills can be explained by growing concern about human capital competitiveness in the UK over the past thirty years. The relative unattractiveness of the alternative of improving employment conditions is due to the fear that doing so would reduce profits, employment growth and competitiveness; an unappealing prospect for the economic liberals who dominate the UK political arena.

Since the late 1990s, within the broad consensus on the need to improve human capital competitiveness lay a growing focus on competing for the "best and brightest" migrant workers. However, as numbers of migrant workers grew over the past decade, concern about a reduction in opportunities for the resident labour force led to a political emphasis on producing the skills needed by employers within the UK rather than importing them. This emphasis developed as the approach to immigration shifted from positive to negative from around 2007-8 (Devitt, 2010). The restrictions imposed on recruiting non-EEA foreign workers from 2010 have given further impulse to efforts to produce skills domestically.

The MAC was charged with ascertaining when it was "sensible" to open up to migrant workers by the Labour government in late 2007. In producing the shortage occupation list the MAC approach to the concept of "sensible" is to consider each occupation with reference to whether employers have explored feasible alternatives to employing immigrants such as training resident workers, raising wages and working conditions or changing production processes. It is underlined that not all options are feasible at all times and that the economic and regulatory environment can make certain responses to labour shortages difficult; for example public budgets can limit wage increases. However, despite this in-depth labour market analysis, the "sensible" test is of limited weight; only a handful of occupations are kept off the list if they have already been deemed skilled 
and in shortage (Interview MAC). This points, once again, to a disjuncture between discourse - in this case on finding alternatives to labour immigration - and policy outputs in Britain.

In the context of a deepening economic recession, the rise of the extreme right British National Party and upcoming national elections, in late 2008, Gordon Brown announced that when an occupation was put on the shortage occupation list, the government would review whether and how more training of resident workers could reduce the need for migrants (Martin and Ruhs, 2010). However, by November 2009 coordination between immigration and education and training policy had still not occurred, as evidenced in the Skills for growth: the National skills strategy report; "Critically, we need to join up their (the MAC's) work with the remit we are giving the UK Commission to turn intelligence about shortages into national training priorities in the skills system." (BIS 2009, p.11).

Indeed, according to an official from the Department for Business, Innovation and Skills, it was not until 2010 that a coordinated policy on immigration and skills development was formalised and that this was in large part a reaction to the limits to be imposed on immigration and a concern with ensuring that employers would be able to source skills in a context of a more restrictive immigration policy; "The skills strategy 2010 was the first time we set out formally what we would do; because of the introduction of the cap and the need for some kind of response in that space" (Interview BIS1). Indeed, new qualifications had been designed for ethnic catering at the end of Labour's period in office in order to attempt to fill chef skill shortages - which accounted for a large proportion of inflows through the shortage occupation route - with resident workers. However, this policy was further strengthened when all but the most highly qualified chefs were taken off the shortage list in 2011.

The Coalition government has also put a lot of rhetorical emphasis on labour competition from Eastern Europe and part of the policy response to this is to stimulate the resident unemployed to take up available jobs, thus reducing intra-EU mobility. The Department for Work and Pensions (DWP) is trying to engage employers to recruit "UK workers" and disabuse the latter of misconceptions they might have about certain sectors (Interview DWP2). Indeed, the impending closure of the Seasonal Agricultural Workers Scheme on the 31st of December 2013 led the DWP to introduce a pilot scheme focusing on training unemployed UK people and persuading them to take up agricultural work (Interview DWP2). However, this policy of substituting migrant workers is still relatively small-scale and levels of 
intra-departmental coordination on this issue are limited (Interview BIS2). Furthermore, employers have questioned the feasibility of the policy, arguing that unlike migrant workers, British school leavers do not have the required skills and are less reliable (Interview HO).

\subsubsection{France}

Direct labour migration to France is, as we have seen above, comparatively limited. As such, until very recently, there has been very little debate on how to reduce it. Indeed, the policy of reducing demand for migrant workers by means of upgrading and revalorising jobs refuted by domestic workers or providing domestic workers with the skills required by employers has been dormant in France since the failed attempt made by Lionel Stoléru, Secretary of State for manual labour and immigration, in the $1970 \mathrm{os}$ (Interview De Wenden).

The debate between the late 1990s and 2013 has rather been on how much and what type of labour immigration should be facilitated in France in order to respond to labour shortages, in the context of relatively high levels of unemployment. However, while direct labour immigration is relatively insignificant in France, it doubled between 2006 and 2008 and the centre-right government began to emphasise domestic alternatives to migrant workers in 2011 in the context of the current economic downturn. According to the decree of the $31^{\text {st }}$ of May published by the Ministries of Interior and Labour, "The priority has to be given to the employment of jobseekers, of French or foreign nationality, already resident in France." This was seen as particularly important given the recent estimate of $23 \%$ unemployment among non-European nationals resident in France. Among other controls, the prefects were instructed to examine whether it would be possible to quickly train jobseekers resident in France in an occupation for which an employer has requested a work permit for a foreign worker (d. l. o.-m. Ministère de l'Intérieur, des collectivités territoriales et de l'immigration et Ministère du travail, de l'emploi et de la santé, 2011). Furthermore, the constitution of the shortage occupation list for non-EU workers in 2011 took into account not just the relationship between job offers and job seekers in particular occupations but also whether workers could be trained in France in particular occupations. This had been less emphasised in 2008 (Interview OLI1).

There is, nonetheless, a shared understanding among stakeholders that migrant workers cannot be replaced by resident workers. Representatives of two French trade unions, CGT and CFDT maintain that the idea of substituting immigrants with resident unemployed is not taken seriously 
in France as the jobs migrants do are mainly low-paid and unattractive to the resident unemployed (CGT2, CFDT2). Furthermore a representative from the employers' federation Medef asserted that the high levels of social protection in France reduce incentives to return to work (Medef).

\section{$4 \quad$ Explaining policy choices}

A recent Financial Times article entitled "Britain "open for business and closed to foreigners"' exemplifies the strength of the Conservative party's anti-immigration rhetoric (Stephens, 2013). Strong anti-immigrant discourse, along with the imposition of a cap on immigration for the first time, among other restrictive measures, certainly give the impression that Britain has returned to a heavily restrictive immigration regime. However, the reality is of course much more nuanced. Indeed, the comparison of British and French responses to foreign labour demand over the past five years leads me to conclude that both states have protected migrant inflows during the current economic crisis due to on-going (though varying) demand for migrant workers in both states. This is particularly the case of official labour migrants in Britain, especially ICTs, and both official and indirect labour migrants, in particular students, in France. This has not stopped British governments from also attempting - albeit on a smallscale - to substitute migrant workers with resident workers by means of training and persuading people to take up jobs in sectors where migrant workers concentrate. This search for alternatives to migration has been less emphasised in France.

In explaining these policy choices, I emphasise converging and diverging dominant economic and social perspectives. Due to the hegemony of liberalism and the attendant global economic integration, human capital competitiveness has come to be viewed as the lynchpin of economic growth in developed economies, which can no longer compete on the basis of cost (Crouch, 2005). As noted above, highly skilled migrant workers are viewed to be important actors in this global skills competition and most developed economies have been facilitating their entry since the late 1990s, including Britain and France. This perspective is partly fuelled by employer groups, in particular those representing multi-nationals, which lobby for access to skilled mobile workers. It is thus not surprising that, despite restrictive immigration policy rhetoric and attempts to reduce inflows of labour immigrants, the highly skilled migrant categories have been protected in both states. This is best exemplified by the fact that ICTs are 
exempt from the numerical cap placed on Tier 2 migrants in 2011, despite the fact that they are the largest group of labour migrants in Britain and are already exempt from the RLMT. Equally exemplary is the fact that the Sarkozy government was unsuccessful in its attempt to restrict non-EU students from being issued with work permits on graduation due to a strong reaction from stakeholders.

There is, however, an important difference between Britain and France in terms of labour immigration; Britain receives far higher numbers every year, approximately 100,000 more than France. This can be partly explained by a more buoyant, flexible labour market and a more globally integrated economy; Britain is the second largest destination for foreign direct investment after the US. Indeed, Britain will continue to be more open to immigration than France due to light touch labour market regulation and a stronger policy focus on courting global financial investment.

The requirements of a globally integrated economy (i.e. highly skilled migrant workers) are at odds with the politics of immigration, which have become progressively contentious in both states. Since the 1980 s and emergence of the FN in France, immigration has become highly politicised and due to continuing high levels of unemployment, any significant opening to labour immigration has long been off the agenda. This makes "invisible" indirect labour immigration comparatively important in France. The populist force of the $\mathrm{FN}$ also explains the return to restrictive labour immigration policy rhetoric in 2011, while the tension between politics and the economy accounts for the fact that, despite policy change, actual inflows of labour immigrants did not decline. Despite the decade of a positive consensus on labour immigration in Britain between the late 1990 and 2007, immigration has once again become something for everybody to point their finger at. In order to attract disgruntled voters in the general election of 2010, the Conservative party pledged to reduce net migration to the tens of thousands. Indeed, politics explains the disjuncture between rhetoric and policy outputs in the British case, as the main focus of the government has been to reduce long-term migration, which contributes to net migration, and consequently temporary migration - for example ICTs coming to the Britain for less than 12 months - has not been restricted to the same degree.

Finally, British attempts to reduce inflows of labour immigrants by training domestic workers in skills perceived to be in shortage is explained elsewhere as having been stimulated by a perceived over-reliance on labour immigration, concerns about the socio-economic impact of labour immigration and more a generalised preoccupation with raising skill levels 
in the country (Devitt, 2010). More recent efforts to persuade the resident unemployed to take up jobs in occupations where there are significant proportions of migrant workers is coherent with the development of active labour market policy in Britain since the 1980s. British social protection has become increasingly conditional on efforts to get back to work with the aim of reducing public expenditure and taxation, increasing the labour supply and keeping wages low (Bonoli, 2008; King, 1995). The recent attempts to direct welfare recipients to "migrant jobs" is the other half of the policy of reducing labour immigration by means of immigration controls (Cameron, 2013). A similar attempt to "re-nationalise" migrant jobs occurred in France in the 1970s, however, it is generally deemed to have been a failure. This policy has not been re-activated during the current crisis due to a generalised understanding that the resident unemployed would not accept to do the low paid jobs migrants do. This can be understood within the French tradition of social protection, which is more generous than that of Britain and traditionally more passive, putting less emphasis on stimulating/obliging a return to the labour market (Clasen and Clegg, 2003).

The stronger focus on substituting migrant workers with domestic workers in Britain is also partly explained by differing levels of labour immigration in the two states. As noted above, Britain has received far higher numbers of immigrants and EU citizens from Central and Eastern Europe over recent years, which has been accompanied by to a rise in antiimmigration sentiment in the country (Boswell, 2008). Indeed, public opinion shows significantly higher levels of closure to immigration in Britain than in France, as exemplified by the 2011 Transatlantic Trends: immigration survey ${ }^{6}$ (Transatlantic Trends, 2012). British governments consequently have stronger incentives to at least appear to be reducing labour immigration than French governments have.

\section{Conclusion}

A basic premise for this article is that we can expect governments to concern themselves with attempting to ensure that employers - both public and private - have access to supplies of labour. Putting labour supply at the centre of this discussion of labour immigration policy in the context of economic downturns enabled me to bring important, hitherto unexplored aspects of labour immigration and welfare policy into the picture. Existing studies of immigration policy during bad times tend to focus on the devel- 
opment of restrictive policies and on the outcomes of those policies. An important finding of previous research is that oftentimes restrictive immigration policy leads to a growth in irregular migration due to on-going employer demand for cheap, compliant labour. This paper supports the basic contention of persisting labour demand during economic downturns and focuses squarely on the role of the state in responding to that demand. It hypothesises and finds evidence for three further policy responses to continuing demand for foreign workers during economic crises; protecting highly skilled labour immigration; facilitating family and student migrants' access to the labour market; and attempts to substitute migrant workers with resident workers.

On this basis, I argue that labour immigration policy theory needs to be updated to take into account how since the late 1990s governments in advanced economies work firmly within a paradigm of global economic integration. Within this interpretive framework, the facilitation of the immigration of highly skilled workers is viewed as a requirement of open competitive economies. As such, we can expect governments to protect highly skilled worker immigration even during economic downturns. Furthermore, labour immigration policy theory needs to expand its perspective to take into account the significance of indirect labour immigration - apart from irregular immigration - in particular, the facilitation of family and student migrant participation in the economy. Finally, theory needs to encompass government attempts to reduce demand for labour immigrants by encouraging resident workers to take up jobs in occupations or sectors with high concentrations of foreign workers; that is immigration control via active labour market policy.

This paper has also uncovered some of the factors, which currently generate the liberal constraint on restrictive immigration policies identified by scholars such as Freeman (1995), Hollifield, (2004) and Joppke, (1998). As regards skilled labour immigration in Britain, employer and diplomatic lobbying in the context of governmental prioritisation of human capital competitiveness ensured that these inflows would be protected. In France, it appears that the political rhetoric around reducing labour immigration was mainly a ploy to siphon votes from the competing FN party and was not reflective of real political will to reduce the already small numbers of foreign workers entering the country each year. Non-EU students' access to the French labour market was protected by protests from universities and students, with a direct interest in retaining this incentive to study in France. Finally, the policy of substituting migrant workers with domestic workers has been constrained in France by a stakeholder 
consensus that the policy is not feasible given differing employment expectations of migrants and domestic workers. The policy is still marginal in the UK and its growth has been constrained by similar doubts regarding the viability of the policy as well as by departmental coordination limitations.

\section{Notes}

1. Migrant workers refer to foreign nationals based abroad who come to a country in order to work.

2. Employers have to show that the role could not be filled from within the resident labour market.

3. The European Economic Area (EEA) provides for the free movement of goods, persons, services and capital through three of four member states of the European Free Trade Association (EFTA) and 27 of 28 member states of the European Union (EU), with Croatia provisionally applying the agreement pending its ratification by all EEA countries.

4. It is, however, important to note that a significant proportion of non-EU work-related inflows to Britain is composed of people coming to take up low-medium skilled work via the Tier 5 Youth Mobility Scheme and non-PBS work visas for domestic workers in private households, amongst other categories. Scott Blinder, 'Non-European Labour Migration to the Uk', (Oxford: Migration Observatory Oxford, 2013). This differs from the French case, where the majority of non-EU work-related flows consist of medium and highly skilled individuals. Ministère De L'intérieur, 'Les Données De L'immigration Professionnelle Et Étudiante Document Préparatoire Au Débat Au Parlement', (Paris, 2013).

5. It is important to note, however, that LFS data probably undercount students, especially those living in dormitories and other communal dwellings.

6. According to the Transatlantic Trends survey, in 2011, $33 \%$ of respondents in France and $57 \%$ of respondents in the UK perceived that there were too many immigrants in their countries.

\section{References}

Bertossi, C. (2008). 'France: the State strives to shape "chosen” immigration', Politiche Migratorie e Modelli di Società (Rome: CeSPI).

BIS (2009). 'Skills for growth: National skills strategy', (London: BIS).

Blinder, S. (2013). 'Non-European Labour Migration to the UK', (Oxford: Migration Observatory Oxford).

Bonoli, G. (2008). 'The Political Economy of Activation: Explaining Cross-National Variation in Active Labour Market Policy', Working Paper De l'IDHEAP, (1), 1-21.

Boswell, C. (2008). 'UK Labour Migration Policy: Permanent Revolution?', (Rome: CeSPI).

Boswell, C. (2009). The Political Uses of Expert Knowledge (Cambridge: Cambridge University Press).

Cameron, D. (2013). 'David Cameron's Immigration speech', in University Campus Suffolk (ed.), (Ipswich). 
CAS (2006). 'Besoins de main-d'œuvre et politique migratoire', (Paris: Centre d'analyse stratégique ). ['Labour shortages and migration policy', Paris: Centre for Strategic Analysis]

Castles, S. (2004). 'Why migration policies fail', Ethnic and Racial Studies, 27 (2), 205-27.

Clasen, J. \& Clegg, D. (2003). 'Unemployment Protection and Labour Market Reform in France and Great Britain in the 1990s: Solidarity Versus Activation?', Journal of Social Policy, $3^{2}$ (3), 361-81.

Cornelius, W. Martin, P. \& Hollifield, J. F. (eds.) (1994). Controlling Immigration. A Global Perspective (Stanford: Stanford University Press).

Crouch, C. (2005). 'Skill formation systems', in S. Ackroyd, et al. (eds.). The Oxford Handbook of Work and Organization (Oxford: OUP).

Devitt, C. (2010). 'The Migrant Worker Factor in labour market policy reform', European Journal of Industrial Relations, 16 (3), 259-75.

Freeman, G. (1995). 'Modes of Immigration Policies in Liberal Democratic States', International Migration Review, 29 (4), 881-913.

Guiraudon, V. \& Joppke, C. (eds.) (2001). Controlling a new migration world (London: Routledge).

Hollifield, J. F. (2004). 'Migration and International Relations: the Liberal Paradox ', in Entzinger, H. et al., (ed.), Migration between States and Markets (Aldershot: Ashgate).

Home Office (2002). 'Secure borders, safe havens: Integration with diversity in modern Britain', in Home Office (ed.), (London).

Joppke, C. (1998). 'Why Liberal States Accept Unwanted Immigration', World Politics 50 (2), 266-93.

King, D. (1995). Actively Seeking Work? The Politics of Unemployment and Welfare Policy in the United States and Great Britain (Chicago: The University of Chicago).

Krings, T. (2009). 'A race to the bottom?' Trade unions, EU enlargement and the free movement of labour', European Journal of Industrial Relations, 15 (1).

Le nouvel observateur (2013). 'La France "n’a pas besoin de maçons et de serveurs" immigrés 22 May 2013'.

Lochak, D. (2006). 'La loi du 24 juillet 2006 relative à l'immigration et à l'intégration 45-55', $L a$ française Regards sur l'actualité, 326, 45-55.

MAC (2009). 'Analysis of the Points Based System Tier 2 and Dependants', (Croydon: Migration Advisory Committee).

Martin, P. \& Ruhs, M. (2010). 'Labor Shortages and US Immigration Reform: Promises and Perils of an Independent Commission', COMPAS WP, No. 81.

Menz, G. (2005). Varieties of Capitalism and Europeanisation: National Responses to the Single Market. (Oxford: Oxford University Press).

Migration Observatory (2011). 'A loose fitting cap: why is the limit on skilled non-EU workers undersubscribed?', (Oxford: University of Oxford).

Ministère de l'Intérieur (2013). 'Les données de l'immigration professionnelle et étudiante Document préparatoire au débat au Parlement', (Paris).

Ministère de l'Intérieur, de l'outre-mer, des collectivités territoriales et de l'immigration et Ministère du travail, de l'emploi et de la santé. (2011). 'Maitrise de l'immigration professionelle', (Paris).

Ministère de l'Intérieur, de l'outre-mer, des collectivités territoriales et de l'immigration, Ministère du travail, de l'emploi et de la santé et Ministère de l'Enseignment Supérieur et de la Recherche. (2012). 'Circulaire du 12 janvier relative à l'accès au marché du travail des diplômés étrangers de niveau au moins équivalent au Master : modalités d'examen des demandes', (Paris).

OECD (2009). 'International Migration Outlook', Sopemi edition (Paris: OECD).

Ruhs, M. \& Martin, P. (2008). 'Numbers vs Rights: Trade-offs and Guestworker Programs', International Migration Review, 42 (1), 249-65.

Schain, M. (2006). 'The Extreme Right and Immigration Policy-Making: Measuring Direct and Indirect Effects', West European Politics, 29 (2), 270-89. 
Somerville, W. (2007). Immigration Under New Labour (Bristol: The Policy Press).

Sparrow, A. (2011). 'Businesses reject call from Iain Duncan Smith to employ more Britons', The Guardian.

Stephens, P. (2013). 'Britain 'Open for Business, Closed to Foreigners' (20th of February 2013)', Financial Times.

Summers, D. (2009). 'Brown stands by British jobs for British workers remark', The Guardian, 3oth of January 2009.

The Economist. (2012). 'Marine Le Pen Waiting in the shadows (11th April 2012)'.

Transatlantic Trends. (2012). 'Transatlantic Trends: Immigration 2011', (German Marshall Fund of United States).

UKBA (2010). 'The Student Immigration System: a consultation', (Croydon: UKBA).

Weil, P. (2006). 'Lettre de Patrick Weil à Nicolas Sarkory sur la réforme, 24 février 2006', (Paris). ['Letter from Patrick Weil to Nicolas Sarkozy concerning the 24th of February 2006 reform']

\section{About the Author}

Camilla Devitt is Assistant Professor in the Department of Sociology, Trinity College Dublin. She obtained her PhD in political and social sciences from the European University Institute, Florence in 2010. Her main research interests are in immigration, welfare and labour market policies.

Email: devittca@tcd.ie

\section{Annex: List of referenced interviews}

\begin{tabular}{|c|c|}
\hline Organisation & Place \& time of interview \\
\hline Home Office (HO) & Croydon, October 2011 \\
\hline Migration Advisory Committee (MAC) & London, October 2011 \\
\hline Business Innovation and Skills Skills and migration division (BIS1) & London, October 2011 \\
\hline Business Innovation and Skills Labour market division (BIS2) & Phonecall, June 2013 \\
\hline Department for Work and Pensions (DWP) & London, April 2013 \\
\hline British Hospitality Association (BHA) & London, October 2011 \\
\hline Trade Union Congress (TUC) & London, October 2011 \\
\hline Office for Labour Immigration, Ministry of the Interior (0LI1) & Paris, February 2012 \\
\hline Office for Labour Immigration, Ministry of the Interior (0LI2) & Paris, May 2013 \\
\hline Medef & Paris, May 2013 \\
\hline \multirow[t]{2}{*}{ Confédération générale du travail (CGT) } & Paris, February 2012 \\
\hline & Paris, May 2013 \\
\hline \multirow[t]{2}{*}{ Confédération française démocratique du travail (CFDT) } & Paris, April 2012 \\
\hline & Paris, May 2013 \\
\hline Catherine de Wenden, CNRS & Paris, February 2012 \\
\hline
\end{tabular}

